\title{
Proteolysis and related enzymatic activities in ten Greek cheese varieties
}

\author{
Agnes Nega • Golfo Moatsou
}

Received: 29 November 2010 /Revised: 28 June 2011 / Accepted: 1 July 2011 /

Published online: 27 August 2011

(C) INRA and Springer Science+Business Media B.V. 2011

\begin{abstract}
The objective of this study was to assess indices of proteolysis and related enzymatic activities of various cheese varieties produced in Greece. Physicochemical composition, extent of proteolysis (nitrogen fraction and reversed-phase high-performance liquid chromatography (RP-HPLC) profiles of cheese soluble fraction) and residual chymosin and plasmin activities were analyzed in 57 commercial samples, grouped according to cheesemaking technologies. The mean values of soluble nitrogen fraction on total nitrogen and trichloroacetic acid-soluble nitrogen fraction on total nitrogen did not differ significantly between the different cheese varieties, with mean values of $16.03 \%$ and $9.97 \%$, respectively. Brined cheeses had the highest mean residual chymosin activity 0.166 International Milk Clotting units (IMCU).g ${ }^{-1}$ of cheese dry matter and the lowest mean plasmin plus plasminogen-derived activity $3.88 \mathrm{U.g}^{-1}$ of cheese. The respective values for Gruyère and hard type cheeses were 0.029 and 0.047 IMCU.g ${ }^{-1}$ of cheese dry matter for chymosin and 6.22 and $6.94 \mathrm{U} . \mathrm{g}^{-1}$ of cheese for plasmin. It was interesting that both enzymatic activities were high in pasta filata type cheeses, i.e., respective mean values of 0.086 IMCU. $\mathrm{g}^{-1}$ of cheese dry matter and $7.42{\mathrm{U} . \mathrm{g}^{-1}}^{-1}$ of cheese. Intermediate regions on the RPHPLC profiles were positively correlated with residual chymosin activity and negatively correlated with plasmin activity. It was concluded that cooking at $\mathrm{pH}$ close to cheesemilk $\mathrm{pH}$ and pressing are the most important technological factors both for proteolysis and activity of major proteolytic enzymes in various cheese varieties.
\end{abstract}

\footnotetext{
A. Nega

Department of Food Technology and Nutrition, Technological Educational Institute (TEI) of Athens, St. Spyridonos Str, 12210 Egaleo, Athens, Greece

G. Moatsou $(\bowtie)$

Department of Food Science and Technology, Agricultural University of Athens, Iera Odos 75, 11855 Athens, Greece

e-mail: mg@aua.gr
} 


\title{
10 种希腊干酪中蛋白水解和相关酶的活性
}

\begin{abstract}
摘要 本文对 10 种希腊干酪的蛋白水解和相关酶的活性进行了研究。分析了 57 个商业干酪的 物理性质和化学组成、蛋白水解程度 (氮组分和干酪液相组分) 、凝乳酶残留和血纤维蛋白 溶酶活性。不同干酪品种中可溶性氮/总氮和三氯乙酸-溶解氮/总氮的平均值分别 $16.03 \%$ 和 $9.97 \%$, 品种之间没有显著性的差异。盐卤干酪凝乳酶残余活性最高, 为 $0.166 \mathrm{IMCU} \cdot \mathrm{g}^{-1}$ (干 基)，而其总血纤维蛋白溶酶(血纤维蛋白溶酶 + 血纤维蛋白溶酶原的衍生活性)的活性最低, 为 $3.88 \mathrm{IMCU} . \mathrm{g}^{-1}$ (干基)。Gruyère和硬质干酪的凝乳酶残余活性分别为 0.029 和 $0.047 \mathrm{IMCU}$. $\mathrm{g}^{-1}$ (干基),其血纤维蛋白溶酶的活性分别为 6.22 和 $6.94 \mathrm{U.g}^{-1}$ (干基)。但是在pasta filata类 型干酪中, 凝乳酶和血纤维蛋白溶酶的活性都较高, 分别为 $0.086 \mathrm{IMCU} . \mathrm{g}^{-1}$ 和 $7.42 \mathrm{U.g}^{-1}$ (干 基)。干酪液相经RP-HPLC分析的结果表明, 干酪液相组成的特性与残余凝乳酶的活性呈正相 关与血纤维蛋白溶酶的活性呈负相关。因此, 对不同类型的干酪, 干酪用乳的 $\mathrm{pH}$ 和压榨是决 定蛋白水解和主要蛋白水解酶活性的关键技术参数。
\end{abstract}

Keywords Proteolysis · Peptide profiles $\cdot$ Residual chymosin $\cdot$ Plasmin $\cdot$ Cheese varieties

关键词 蛋白水解·肽特性·残余凝乳酶·血纤维蛋白溶酶·干酪品种

\section{Introduction}

Cheese characteristics are configured by the cheesemilk composition, cheesemaking technology, and ripening conditions (Amenu and Deeth 2007). There are several excellent review papers in the literature about the technological factors and the biochemical pathways related to cheese ripening. A great part of them have been published during the last decade and present the complexity and importance of proteolysis. In summary, proteolysis induces changes in the curd structure through the hydrolysis of the casein network and the decrease of water activity due to the water bound by the carboxyl and amino groups of the peptides. It contributes directly to the sensory characteristics of cheese by accumulating small peptides and free amino acids in the cheese mass. Moreover, the liberated amino acids are substrates for secondary changes resulting in the formation of volatile compounds. The major enzymatic activities involved in cheese ripening come from residual coagulant, indigenous milk proteinases, and bacterial proteolytic enzymes and they are affected by the cheesemaking and ripening conditions (e.g., McSweeney et al. 2006; Sousa et al. 2001). Therefore, the study of proteolysis is very essential for cheese science and technology.

Due to the complexity of the involved phenomena a variety of chemical, physicochemical, and enzymatic methods are put into practice for the assessment of proteolysis in cheese (Sousa et al. 2001). The study of nitrogenous fractions has been reported many times for many cheese varieties but the opposite is true for the determination of enzymatic activities in cheese. The first studies about residual chymosin activity in cheese were mainly about the partition of the enzymes between curd and whey and showed that the most important factors are the type of rennet, thermal treatment of the curd, and $\mathrm{pH}$ during drainage (Guinee and Wilkinson 1992). During the last years, an enzymatic method specific for aspartic proteinases (Hurley et al. 1999) has been added to the methods used for the determination of residual 
chymosin in cheese (Baer and Collin 1993). Using this method, recent studies have been published about the factors that affect the retention of rennet in cheese curd and the residual coagulant activity in different cheese varieties in relation to cheesemaking technology (Bansal et al. 2007, 2009).

Plasmin activity has been studied in various cheese varieties, i.e., Cheddar (Farkye and Fox 1992), Gouda (Scherze et al. 1994), Swiss type (Baer et al. 1997), Danbo (Benfeldt et al. 1997), Mozzarella type (Somers et al. 2002), and miniature (Somers and Kelly 2002) cheeses. More recently, plasmin activity has been determined in Italian cheeses and curds made from ovine or caprine milk (Albenzio et al. 2004; Cortellino et al. 2006). The comparative studies of Richardson and Pearce (1981) and Dupont and Grappin (1998) have showed that the role of plasmin in cheese proteolysis varies greatly as it is affected by the cheesemaking technology.

The aim of the present work was the assessment of proteolysis and related enzymatic activities in various Greek cheese varieties in regard to different cheesemaking and ripening conditions. A common feature of these cheeses is their rather long ripening periods that are usually greater than 2 months. Cheese samples from different cheese groups, i.e., brined, Gruyère, hard, and pasta filata type produced mainly from ovine milk or from its mixtures with caprine milk, were analyzed. The new element of this study is the comparative assessment of the extent of proteolysis of various cheese types in relation to two major proteolytic factors, i.e., residual chymosin and plasmin activity.

\section{Materials and methods}

\subsection{Cheese samples}

Fifty-seven market samples of various traditional cheeses, most of them being protected designation of origin varieties, produced in Greece using various cheesemaking technologies (see Table 1) were analyzed. The number of samples for each cheese variety was more or less in accordance to the respective production quantities.

\subsection{Physicochemical analyses}

The $\mathrm{pH}$ was determined by means of a combined glass electrode in a dispersion of graded cheese in distilled water (1:1 ratio). Cheese moisture, fat, and protein content of the samples were determined as previously described (Moatsou et al. 2001). Ash was determined after heating cheese portions at $550{ }^{\circ} \mathrm{C}$ in a muffle furnace for about $4 \mathrm{~h}$. The $\mathrm{NaCl}$ content was determined by the potentiometric titration method (International Standard ISO 5943/IDF 88 2006).

\subsection{Assessment of proteolysis - determination of soluble nitrogen fractions}

Fifteen gram of cheese was homogenized in $50 \mathrm{~g}$ of distilled water using a Stomacher apparatus. After the addition of $135 \mathrm{~mL}$ distilled water, the cheese dispersion was moderately stirred for $30 \mathrm{~min}$ at $40{ }^{\circ} \mathrm{C}$ and $\mathrm{pH}$ was adjusted at $\mathrm{pH} 4.4$ using 1 mol.L $\mathrm{L}^{-1} \mathrm{HCl}$. Following the addition of $40 \mathrm{~mL}$ distilled water, the 
Table 1 Important technological features of the cheese varieties analyzed in the present study (Greek Codex of Foodstuff and Drinks 2009)

Code Cheese variety Important technological features

Brined

B1 Feta

Ovine or mixtures of ovine and caprine cheese milk; cutting into cubes of $2 \times 2 \times 2 \mathrm{~cm}$, no cooking, no pressing; draining by gravity; ripening in brine $\left(\sim 7 \mathrm{~g} . \mathrm{NaCl} \cdot 100 \mathrm{~mL}^{-1}\right)$

B2 Kalathaki Limnou

Ovine or mixtures of ovine and caprine cheese milk; cheesemaking technology similar to that of Feta but draining and acidification of the curd take place in special cylindrical molds, ripening in brine $\left(\sim 7\right.$ g. $\left.\mathrm{NaCl} \cdot 100 \mathrm{~mL}^{-1}\right)$

B3 Sfela

Ovine or mixtures of ovine and caprine cheese milk; cutting into very small pieces ${ }^{\mathrm{a}}$, mild cooking at $38-40{ }^{\circ} \mathrm{C}$, mild pressing, ripening in brine $\left(\sim 20 \mathrm{~g} . \mathrm{NaCl} \cdot 100 \mathrm{~mL}^{-1}\right)$, high salt content

Gruyère type

G1 Graviera Kritis

Ovine or mixtures of ovine and caprine cheese milk; cutting into very small pieces ${ }^{\mathrm{a}}$, high-cooking at $50-52{ }^{\circ} \mathrm{C}$ for more than $30 \mathrm{~min}$, intense mechanical pressing; low salt content

G2 Graviera Naxou

Bovine or mixtures of bovine with limited quantities of ovine and caprine cheese milk; cutting into very small pieces ${ }^{\mathrm{a}}$, high cooking at $50{ }^{\circ} \mathrm{C}$ for about $60 \mathrm{~min}$, intense mechanical pressing; low salt content

Hard type

H1 Kefalograviera

Ovine or mixtures of ovine and caprine cheese milk; cutting into small pieces ${ }^{\mathrm{b}}$, medium cooking at $\sim 48{ }^{\circ} \mathrm{C}$ for about $30 \mathrm{~min}$, intense mechanical pressing, high salt content

H2 Ladotyri Mytilinis

Ovine or mixtures of ovine and caprine cheese milk; cutting into very small pieces ${ }^{\mathrm{a}}$, mild cooking at $43-45^{\circ} \mathrm{C}$; mild pressing by hand; after a 3 months ripening period cheese may be kept in olive oil

H3 San Michali

Partially skimmed bovine cheese milk; cutting into small pieces ${ }^{\mathrm{b}}$; medium cooking at $\sim 48{ }^{\circ} \mathrm{C}$ for about $30 \mathrm{~min}$; intense mechanical pressing

Pasta filata type

P1 Kasseri

P2 Metsovone

Ovine or mixtures of ovine and caprine cheese milk; pasta filata processing ${ }^{\mathrm{c}}$

Bovine or mixtures of bovine with limited quantities of ovine and caprine cheese milk; pasta filata processing ${ }^{\text {c; }}$ after a 3-month ripening period the cheese is smoked

\footnotetext{
${ }^{\text {a }}$ Similar in size to a grain of rice

${ }^{\mathrm{b}}$ Similar in size to a grain of corn

${ }^{\mathrm{c}}$ Biologically acidified cheese curd $(\mathrm{pH} 5.2)$ is kneaded and stretched in hot water $\left(\sim 80^{\circ} \mathrm{C}\right)$
}

suspension was allowed to stand for $20 \mathrm{~min}$ at room temperature. Then, filtration through a Whatman no 40 filter paper was carried out and $25 \mathrm{~mL}$ of the filtrate was used for Kjeldahl analysis (Moatsou et al. 2001; Moschopoulou et al. 2007) in duplicate. This fraction was symbolized as soluble nitrogen (SN). An equal volume of trichloroacetic acid (TCA) $24 \%(w / v)$ was added to a particular volume of SN filtrate. The mixture was kept at $4{ }^{\circ} \mathrm{C}$ overnight and after filtration through Whatman 
no 40 filter paper, $40 \mathrm{~mL}$ of the filtrate were analyzed by the Kjeldahl method in duplicate. This fraction was symbolized as TCA-SN (trichloroacetic acid soluble nitrogen). Of $\mathrm{H}_{2} \mathrm{SO}_{4}, 33.6 \mathrm{~mL}\left(3.95 \mathrm{~mol} . \mathrm{L}^{-1}\right)$ and $14.4 \mathrm{~mL}$ phosphotungstic acid (PTA) $33.3 \%(w / v)$ were added to $60 \mathrm{~mL}$ of SN. The mixture was kept at $4{ }^{\circ} \mathrm{C}$ overnight and after filtration through Whatman no 40 filter paper, $40 \mathrm{~mL}$ of the filtrate were analyzed by the Kjeldahl method in duplicate. This fraction was symbolized as phosphotungstic acid soluble nitrogen (PTA-SN).

\subsection{Assessment of peptide profiles}

Analyses of $70 \mu \mathrm{L}$ SN extracts were carried out using an automated HPLC system of Waters (Waters, 34 Marple Street, Milford, MA, 01757, USA), consisting of Waters 600 pump, diode array UV/Vis Waters 996 detector, a helium degasser and Waters 717 autosampler. Data acquisition and processing were performed by the Millenium v. 2.15 (1994, Waters Corp.). A reversed-phase high-performance liquid chromatography (RP-HPLC) C18 column equipped with a guard column EC 250/4 Nucleosil 300-5 (Macherey-Nagel, Düren, Germany) was used. Solvent A contained 1 mL.L ${ }^{-1}$ trifluroacetic acid (TFA) in ultra pure water; solvent B contained $1 \mathrm{~mL} . \mathrm{L}^{-1}$ TFA in a mixture of $600 \mathrm{~mL}$ acetonitrile and $399 \mathrm{~mL}$ ultra pure water. Flow rate was $0.75 \mathrm{~mL}$. $\min ^{-1}$ and the sample was eluted at room temperature firstly with $100 \% \mathrm{~A}$ for 10 min, then with a gradient of $0-80 \%$ B over 80 and finally with $100 \%$ B for $10 \mathrm{~min}$. The absorbance of the eluate was monitored at $220 \mathrm{~nm}$. All solvents and samples were filtered through $0.45 \mu \mathrm{m}$ Millex-HV filters (Millipore, Cork, Ireland).

\subsection{Measurement of residual coagulant activity}

The method used was based on the method of Hurley et al. (1999) used also by Bansal et al. (2007, 2009). Briefly, $500 \mathrm{mg}$ of grated cheese were dispersed in $1 \mathrm{~mL}$ of 0.2 mmol. $\mathrm{L}^{-1}$ trisodium citrate buffer $\mathrm{pH} 7.0$ and then incubated at $37{ }^{\circ} \mathrm{C}$ for $30 \mathrm{~min}$ under periodical stirring. The fat layer was separated by centrifugation $1,000 \times \mathrm{g}$ for $5 \mathrm{~min}$. An aliquot of $210 \mu \mathrm{L}$ of cheese dispersion was mixed with $600 \mu \mathrm{L}$ of $200 \mathrm{mmol} . \mathrm{L}^{-1}$ sodium formate $\mathrm{pH} 3.2$ and $45 \mu \mathrm{L}$ of the substrate dilution (1 mg.mL ${ }^{-1}$ of the synthetic heptapeptide H-Pro-Thr-Clu-Phe-[p-nitro-Phe]-ArgLeu-OH, H-1002, Bachem, Bubendorf, Switzerland). After incubation at $37{ }^{\circ} \mathrm{C}$ for $6 \mathrm{~h}$ the enzymatic reaction was terminated by heat treatment at $70{ }^{\circ} \mathrm{C}$ for $10 \mathrm{~min}$. The assay mixture was centrifuged at $16,000 \times g$ for $10 \mathrm{~min}$ and $100 \mu \mathrm{L}$ of the supernatant filtered through $0.45 \mu \mathrm{m}$ filter paper was analyzed using a C8 RPcolumn $4.6 \times 250 \mathrm{~mm}, 5 \mu \mathrm{m}$ particle size, $300 \AA$ pore size (Macherey-Nagel, Düren, Germany) by the elution method reported by Hurley et al. (1999). For the determination of the retention time of the substrate, assays including substrate without cheese extract or substrate incubated with rennet were carried out. The results were confirmed by analyzing an assay mixture of cheese extract/substrate heated at $70{ }^{\circ} \mathrm{C}$ for $5 \mathrm{~min}$. Under these conditions, the hydrolysis of the substrate was inhibited. Since this method is also used for the determination of cathepsin D, some assay mixtures were heated at $60{ }^{\circ} \mathrm{C}$ for $3 \mathrm{~min}$ to inactivate chymosin but not cathepsin D. Analysis showed much lower hydrolysis of the substrate compared to that induced by the nonheated controls. 
The quantification of residual rennet was based on the analysis of cheese extracts spiked with known quantities of rennet. A stock dilution of classical calf rennet (Naturen, Chr.Hansen, Hørsholm, Denmark) in a buffer acetic acid/sodium acetate pH 5.5 was used for spiking. Estimation was based on a curve that was constructed using the area units of the peak resulted from substrate hydrolysis and the International Milk Clotting units (IMCU) corresponded to the added rennet dilution in the spiked samples.

\subsection{Measurement of plasmin activity}

A citrate dispersion of cheese was used for the plasmin assay. The preparation of cheese extract was based on the method of Benfeldt et al. (1997). In brief, $10 \mathrm{~g}$ of grated cheese were mixed with $90 \mathrm{~mL}$ of trisodium citrate 0.1 mol. $\mathrm{L}^{-1}$ containing 12 mmol. $\mathrm{L}^{-1} \varepsilon$-aminocaproic acid (EACA). This low concentration of EACA $(\sim 11 \mathrm{mM})$ facilitates the dissociation of plasmin/plasminogen from the micelles and its migration to the soluble phase (Politis et al. 1993).

The mixture was stirred at room temperature for $45 \mathrm{~min}$ followed by an incubation period of $30 \mathrm{~min}$ at $45^{\circ} \mathrm{C}$ in a moderately shaking water bath. After centrifugation for $25,000 \times g$ for $15 \mathrm{~min}$ at $5^{\circ} \mathrm{C}$, the supernatant under the fat layer was removed and kept at $-20{ }^{\circ} \mathrm{C}$ until analysis. The assay was based on the hydrolysis of the synthetic substrate D-Val-Leu-Lys-P-nitroanilide dihydrochloride (V7127, Sigma-Aldrich Chemie, Munich, Germany). Each well of the microtiter plate contained $20 \mu \mathrm{L}$ of cheese supernatant, $20 \mu \mathrm{L}$ plow units urokinase (MP9039-53-6, MP Biomedicals Inc., France) for plasminogen activation and $170 \mu \mathrm{L}$ of $0.1 \mathrm{~mol} . \mathrm{L}^{-1}$ Tris/ $\mathrm{HCl}$ buffer solution pH 7.4 containing 0.6 mmol. $\mathrm{L}^{-1}$ of the substrate. After incubation for $3 \mathrm{~h}$ at $37{ }^{\circ} \mathrm{C}$, the absorbance at $405 \mathrm{~nm}$ was recorded at hourly intervals. A sample without cheese supernatant was used as control. Plasmin plus plasminogen-derived activity was determined for the linear part of the A405/time curve. One unit of plasmin plus plasminogen derived activity corresponded to an increase of 0.1 absorbance units in $60 \mathrm{~min}$. Each cheese sample was analyzed in duplicate.

\subsection{Statistical analysis}

The software Statgraphics Plus for windows 2.1 (Manugistics, Inc., Rockville, MA, 20852, USA) was used for the statistical analysis. Analysis of variance was applied to test the effect of cheese variety on all variables. Further testing was carried out by a multiple range test procedure using the Duncan method $(P<0.05)$. Principal component analysis (PCA) was applied to all analyses results. The relationship between various variables was investigated by regression analysis; the estimated correlations were considered statistically significant at $P<0.01$.

\section{Results and discussion}

\subsection{Physicochemical composition}

The important technological features of the Greek cheese varieties of the present study are shown in Table 1 . The gross composition of cheeses presented in Table 2 
was in general in accordance to the legal definitions about maximum moisture and minimum fat on dry matter of Greek Codex Alimentarius (Greek Codex of Foodstuff and Drinks 2009). Feta (B1) and Kalathaki (B2) brined cheeses had the lowest ratio of protein to fat $(\sim 0.65)$ as a result of their cheesemaking technology. Curd cutting in rather big pieces and the lack of scalding and pressure (Table 2) favors the retention of fat in the cheese curd. The very opposite happened with the H3 cheese named San Michali (ratio, 1:24). This cheese is made from partially skimmed milk and its manufacture comprises cutting into small pieces, cooking, and intense mechanical pressing (Table 1).

The cheese varieties of the present study can be grouped according to their $\mathrm{pH}$ values. Cheeses manufactured with coarse cutting and without cooking and pressing, i.e., brined cheeses $\mathrm{B} 1$ and $\mathrm{B} 2$ with rather high moisture content had very low $\mathrm{pH}$ values as it is expected for these varieties. Hard, Gruyère, and pasta filata type cheeses had $\mathrm{pH}$ values $>5.5$ as a result of the limited acidification of cheese curd during the first hours after manufacture. Decrease of lactose concentration caused by

Table 2 Physicochemical composition of Greek cheese varieties, expressed in $\mathrm{g} 100 \mathrm{~g}^{-1}$ of cheese (mean \pm standard deviation)

\begin{tabular}{|c|c|c|c|c|c|c|c|c|c|}
\hline Code $^{\mathrm{a}}$ & Cheese variety & Moisture & Fat & $\mathrm{FDM}^{\mathrm{b}}$ & Protein & Ash & Salt & $\mathrm{S} / \mathrm{M}^{\mathrm{c}}$ & $\mathrm{pH}$ \\
\hline \multicolumn{10}{|l|}{ Brined } \\
\hline $\begin{array}{l}\text { B1 } \\
\text { (19) }\end{array}$ & Feta & $\begin{array}{c}53.21 \pm \\
4.20\end{array}$ & $\begin{array}{c}25.77 \pm \\
2.61\end{array}$ & $\begin{array}{c}55.09 \pm \\
2.91\end{array}$ & $\begin{array}{c}17.55 \pm \\
1.88\end{array}$ & $\begin{array}{r}3.20 \pm \\
0.38\end{array}$ & $\begin{array}{r}2.34 \pm \\
0.68\end{array}$ & $\begin{array}{r}4.20 \pm \\
1.12\end{array}$ & $\begin{array}{r}4.68 \pm \\
0.35\end{array}$ \\
\hline $\begin{array}{l}\mathrm{B} 2 \\
\text { (3) }\end{array}$ & $\begin{array}{r}\text { Kalathaki } \\
\text { Limnou }\end{array}$ & $\begin{array}{c}56.07 \pm \\
2.87\end{array}$ & $\begin{array}{c}23.80 \pm \\
3.03\end{array}$ & $\begin{array}{c}54.05 \pm \\
3.33\end{array}$ & $\begin{array}{c}15.23 \pm \\
1.37\end{array}$ & $\begin{array}{r}4.08 \pm \\
0.13\end{array}$ & $\begin{array}{r}3.30 \pm \\
0.33\end{array}$ & $\begin{array}{r}5.55 \pm \\
0.59\end{array}$ & $\begin{array}{r}4.48 \pm \\
0.23\end{array}$ \\
\hline $\begin{array}{l}\text { B3 } \\
\text { (3) }\end{array}$ & Sfela & $\begin{array}{c}42.20 \pm \\
2.28\end{array}$ & $\begin{array}{c}28.40 \pm \\
1.97\end{array}$ & $\begin{array}{c}49.10 \pm \\
1.51\end{array}$ & $\begin{array}{c}21.12 \pm \\
0.72\end{array}$ & $\begin{array}{r}7.58 \pm \\
0.63\end{array}$ & $\begin{array}{r}5.75 \pm \\
0.62\end{array}$ & $\begin{array}{c}12.02 \pm \\
1.53\end{array}$ & $\begin{array}{r}5.07 \pm \\
0.12\end{array}$ \\
\hline \multicolumn{10}{|c|}{ Gruyère type } \\
\hline $\begin{array}{l}\text { G1 } \\
\text { (6) }\end{array}$ & $\begin{array}{c}\text { Graviera } \\
\text { Kritis }\end{array}$ & $\begin{array}{c}33.76 \pm \\
2.28\end{array}$ & $\begin{array}{c}34.72 \pm \\
2.04\end{array}$ & $\begin{array}{c}52.42 \pm \\
2.72\end{array}$ & $\begin{array}{c}26.97 \pm \\
2.74\end{array}$ & $\begin{array}{r}4.47 \pm \\
0.36\end{array}$ & $\begin{array}{r}1.78 \pm \\
0.41\end{array}$ & $\begin{array}{r}5.02 \pm \\
1.13\end{array}$ & $\begin{array}{r}5.56 \pm \\
0.23\end{array}$ \\
\hline $\begin{array}{l}\mathrm{G} 2 \\
\text { (3) }\end{array}$ & $\begin{array}{r}\text { Graviera } \\
\text { Naxou }\end{array}$ & $\begin{array}{c}35.82 \pm \\
0.56\end{array}$ & $\begin{array}{c}32.32 \pm \\
1.37\end{array}$ & $\begin{array}{c}49.80 \pm \\
1.71\end{array}$ & $\begin{array}{c}27.29 \pm \\
1.06\end{array}$ & $\begin{array}{r}3.95 \pm \\
0.05\end{array}$ & $\begin{array}{r}1.46 \pm \\
0.21\end{array}$ & $\begin{array}{r}3.93 \pm \\
0.59\end{array}$ & $\begin{array}{r}5.45 \pm \\
0.04\end{array}$ \\
\hline \multicolumn{10}{|c|}{ Hard type } \\
\hline $\begin{array}{l}\mathrm{H} 1 \\
(5)\end{array}$ & Kefalograviera & $\begin{array}{c}37.77 \pm \\
1.23\end{array}$ & $\begin{array}{c}31.25 \pm \\
2.72\end{array}$ & $\begin{array}{c}50.17 \pm \\
3.56\end{array}$ & $\begin{array}{c}24.46 \pm \\
1.22\end{array}$ & $\begin{array}{r}5.96 \pm \\
0.47\end{array}$ & $\begin{array}{r}3.51 \pm \\
0.46\end{array}$ & $\begin{array}{r}8.49 \pm \\
1.01\end{array}$ & $\begin{array}{r}5.46 \pm \\
0.04\end{array}$ \\
\hline $\begin{array}{l}\mathrm{H} 2 \\
\text { (3) }\end{array}$ & $\begin{array}{l}\text { Ladotyri } \\
\text { Mytilinis }\end{array}$ & $\begin{array}{c}32.58 \pm \\
0.63\end{array}$ & $\begin{array}{c}35.57 \pm \\
0.64\end{array}$ & $\begin{array}{c}53.22 \pm \\
1.41\end{array}$ & $\begin{array}{c}26.60 \pm \\
0.71\end{array}$ & $\begin{array}{r}4.86 \pm \\
0.30\end{array}$ & $\begin{array}{r}2.17 \pm \\
0.17\end{array}$ & $\begin{array}{r}6.25 \pm \\
0.35\end{array}$ & $\begin{array}{r}5.52 \pm \\
0.04\end{array}$ \\
\hline $\begin{array}{l}\mathrm{H} 3 \\
\text { (3) }\end{array}$ & San Michali & $\begin{array}{c}34.18 \pm \\
1.52\end{array}$ & $\begin{array}{c}26.23 \pm \\
1.70\end{array}$ & $\begin{array}{c}38.65 \pm \\
2.23\end{array}$ & $\begin{array}{c}32.50 \pm \\
1.78\end{array}$ & $\begin{array}{r}6.17 \pm \\
0.20\end{array}$ & $\begin{array}{r}3.04 \pm \\
0.16\end{array}$ & $\begin{array}{r}8.19 \pm \\
0.74\end{array}$ & $\begin{array}{r}5.69 \pm \\
0.19\end{array}$ \\
\hline \multicolumn{10}{|c|}{ Pasta filata type } \\
\hline $\begin{array}{l}\text { P1 } \\
\quad(9)\end{array}$ & Kasseri & $\begin{array}{c}40.86 \pm \\
2.45\end{array}$ & $\begin{array}{c}28.74 \pm \\
3.55\end{array}$ & $\begin{array}{c}48.49 \pm \\
4.79\end{array}$ & $\begin{array}{c}25.75 \pm \\
0.85\end{array}$ & $\begin{array}{r}4.08 \pm \\
0.49\end{array}$ & $\begin{array}{r}1.65 \pm \\
0.63\end{array}$ & $\begin{array}{r}3.92 \pm \\
1.31\end{array}$ & $\begin{array}{r}5.67 \pm \\
0.17\end{array}$ \\
\hline $\begin{array}{l}\text { P2 } \\
\text { (3) }\end{array}$ & Metsovone & $\begin{array}{c}40.31 \pm \\
3.12\end{array}$ & $\begin{array}{c}29.05 \pm \\
1.93\end{array}$ & $\begin{array}{c}48.65 \pm \\
1.37\end{array}$ & $\begin{array}{c}26.24 \pm \\
1.09\end{array}$ & $\begin{array}{r}3.93 \pm \\
0.29\end{array}$ & $\begin{array}{r}2.26 \pm \\
0.05\end{array}$ & $\begin{array}{r}5.32 \pm \\
0.39\end{array}$ & $\begin{array}{r}5.50 \pm \\
0.04\end{array}$ \\
\hline
\end{tabular}

\footnotetext{
${ }^{a}$ Number of samples in parenthesis

${ }^{\mathrm{b}}$ Fat on dry matter

${ }^{\mathrm{c}}$ Salt-in-moisture
} 
the fine cutting, cooking, and pressing that facilitates whey expulsion and the effect of cooking on lactic acid bacteria restrain the lactic acid accumulation in the cheese curd. Mild cooking and pressing resulted in the intermediate $\mathrm{pH}$ value of Sfela cheese (B3).

From Table 2, it was evident that salt-in-moisture content varies greatly within various cheese types. Gruyère type (Graviera Kritis (G1) and Graviera Naxou (G2)) and Kasseri cheese were in general low-salted cheese varieties. B3, which is immersed in very dense brine $\left(\sim 20 \mathrm{~g} . \mathrm{NaCl} .100 \mathrm{~mL}^{-1}\right)$ following dry salting for $24 \mathrm{~h}$, had a very extreme salt-in-moisture content, higher than $10 \%$. The salt-in-moisture content of hard type cheeses (Kefalograviera (H1), Ladotyri Mytilinis (H2), and San Michali cheese (H3)) was much higher than $5 \%$.

\subsection{Extent of proteolysis}

The nitrogen fractions of the cheeses are presented in Table 3. The fraction of SN consists of all proteolysis products and of the whey proteins that have been retained in the curd. The fraction of nitrogen soluble in 12\% TCA (TCA-SN) includes free amino acids and medium- and small-size peptides with 2-20 amino acid residues, whereas free amino acids and very small peptides up to $600 \mathrm{~g} \cdot \mathrm{mol}^{-1}$ consists the fraction soluble in 5\% PTA (PTA-SN; Sousa et al. 2001). Although, proteolysis is a complex procedure, it can be considered that PTA-SN expresses its end-products.

Table 3 Extent of proteolysis of various cheese varieties, expressed as percentages of nitrogen fractions on total nitrogen (mean value \pm standard deviation)

\begin{tabular}{lllll}
\hline Code $^{\mathrm{a}}$ & Cheese variety & $\% \mathrm{OSN} / \mathrm{TN}^{\mathrm{b}}$ & $\% \mathrm{TCA}-\mathrm{SN} / \mathrm{TN}^{\mathrm{c}}$ & ${ }^{\circ} \mathrm{PTA}-\mathrm{SN} / \mathrm{TN}^{\mathrm{d}}$ \\
\hline Brined & & & & \\
B1 (19) & Feta & $13.8 \pm 2.9$ & $9.9 \pm 2.4$ & $4.1 \pm 1.9$ \\
B2 (3) & Kalathaki Limnou & $15.8 \pm 0.4$ & $10.7 \pm 1.1$ & $4.0 \pm 1.4$ \\
B3 (3) & Sfela & $13.9 \pm 2.9$ & $9.1 \pm 2.7$ & $4.5 \pm 1.6$ \\
Gruyère type & & & & \\
G1 (6) & Graviera Kritis & $17.3 \pm 3.8$ & $9.5 \pm 2.3$ & $5.1 \pm 1.1$ \\
G2 (3) & Graviera Naxou & $18.7 \pm 5.6$ & $8.1 \pm 4.0$ & $3.2 \pm 2.1$ \\
Hard type & & & & \\
H1 (5) & Kefalograviera & $18.5 \pm 2.7$ & $10.6 \pm 2.0$ & $1.4 \pm 0.5$ \\
H2 (3) & Ladotyri Mytilinis & $14.4 \pm 3.4$ & $9.1 \pm 2.1$ & $3.6 \pm 1.4$ \\
H3 (3) & San Michali & $17.0 \pm 3.5$ & $11.5 \pm 0.9$ & $5.6 \pm 1.3$ \\
Pasta filata type & & & & \\
P1 (9) & Kasseri & $18.3 \pm 5.2$ & $9.3 \pm 2.4$ & $4.3 \pm 1.5$ \\
P2 (3) & Metsovone & $17.0 \pm 3.9$ & $13.6 \pm 3.5$ & $7.9 \pm 2.3$ \\
\hline
\end{tabular}

\footnotetext{
${ }^{a}$ Number of samples in parenthesis

${ }^{\mathrm{b}}$ Soluble nitrogen

${ }^{\mathrm{c}}$ 12\% Trichloroactic acid-soluble N

${ }^{\mathrm{d}} 5 \%$ Phosphotungstic acid-soluble N 
In general, the expression of nitrogen fraction as percentage of total nitrogen (TN) normalizes the results, because the effect of moisture content is excluded. Proteolysis, in terms of both SN and low-molecular weight nitrogen fractions (i.e., TCA-SN, PTA-SN) expressed on cheese weight was the lowest in brined cheeses. The main reason is the higher moisture content of Feta and Kalathaki (53-56\%) compared to the other cheese groups and the very high salt-in-moisture of Sfela, $\sim 12 \%$ (Table 2). Furthermore, migration of whey proteins and soluble proteolysis products into the brine (Alichanidis and Polychroniadou 2008) limits the concentration of these products in the cheese mass. Surprisingly, very high values of soluble $\mathrm{N}$ fractions have been found in pasta filata type cheeses, despite the severe thermal treatment of the cheesemass involved in their manufacture, which was expected to inactivate major proteolytic factors.

According to analysis of variance, there were no statistically significant differences $(P>0.05)$ among the mean values of nitrogen fractions. To our opinion, TCA$\mathrm{SN}$ and \%TCA-SN/TN are more appropriate indices for the comparison of proteolysis extent of different cheese varieties because they do not include whey proteins. The retention of whey proteins in the curd is associated to cheese moisture and therefore to cheesemaking conditions and can affect SN and \% SN/TN values.

\subsection{Residual chymosin activity}

The residual chymosin and plasmin plus plasminogen-derived activities in cheeses are presented in Table 4. The high residual activity in brined cheeses could be expected due to their low $\mathrm{pH}$ (mean $\mathrm{pH}$ 4.48-5.07) during both draining (Bansal et al. 2007; Guinee and Wilkinson 1992) and ripening stages. Also, in white-brined cheeses B1 and B2 no curd cooking is involved whereas in B3 very mild cooking is applied (Table 1). Moreover, traditional rennet is used for Sfela cheese, the activity of which expressed in IMCU varies considerably (Moschopoulou et al. 2007).

From the results, it is evident that the high cooking at $50-52{ }^{\circ} \mathrm{C}$ for at least $30 \mathrm{~min}$ affects negatively the residual chymosin of the two Gruyère type cheeses as happens with Gruyère cheeses in general (Guinee and Wilkinson 1992). Rather higher levels of residual chymosin have been found in the hard type cheeses, in which the cooking conditions are in general milder and the salt content higher than that in Gruyere type cheeses (Table 1). Hayes et al. (2002) have found that in both Cheddar and Emmental curd pieces and 1-day-old cheeses, the residual chymosin activity was similar, contrast to the decreased chymosin-induced proteolysis observed during storage of Swiss cheese slurry. It has been reported that during cooking at temperatures up to $55^{\circ} \mathrm{C}$, the enzyme is partially and reversibly denatured and can be partially reactivated during ripening (Hayes et al. 2002, 2004). Moreover, according to Hayes et al. (2001), residual chymosin activity in high-cooked cheeses may be partially attributed to cathepsin $\mathrm{D}$, which is less heat-labile than chymosin and hydrolyses the assay substrate similarly to chymosin under the same conditions. However, no evidence was observed supporting this suggestion (Section 2.5). Furthermore, the quantity of this enzyme in the cheese milk is low and its activity is mainly found in milk whey and not in the casein fraction (Hayes et al. 2001).

Surprisingly, as happened with proteolysis data, a considerable residual chymosin activity was found in pasta filata cheeses, especially in Metsovone cheese (P2). Pasta filata processing is carried out at very high temperatures $\left(\sim 80^{\circ} \mathrm{C}\right)$ that are expected 
Table 4 Major enzymatic proteolytic activities in various cheese varieties (mean value \pm standard deviation)

\begin{tabular}{|c|c|c|c|c|}
\hline $\operatorname{Code}^{\mathrm{a}}$ & Cheese variety & $\begin{array}{l}\text { Residual chymosin } \\
\text { (IMCU } \cdot{ }^{-1} \text { of cheese } \\
\text { dry matter) }{ }^{\mathrm{b}, \mathrm{d}}\end{array}$ & $\begin{array}{l}\text { Plasmin }+ \text { plasminogen } \\
\text { derived activity } \\
\left(\mathrm{U} \cdot \mathrm{g}^{-1} \text { of cheese }\right)^{\mathrm{c}}\end{array}$ & $\begin{array}{l}{[\text { Plasmin }+ \text { plasminogen }} \\
\text { derived activity }] /[\text { protein } \\
\text { content of cheeses }]^{\mathrm{d}}\end{array}$ \\
\hline \multicolumn{5}{|l|}{ Brined } \\
\hline B1 (19) & Feta & $0.164 \pm 0.059 \mathrm{a}$ & $3.58 \pm 0.91 \mathrm{a}$ & 0.204 \\
\hline B2 (3) & Kalathaki Limnou & $0.177 \pm 0.043 \mathrm{a}$ & $4.42 \pm 0.08 \mathrm{a}, \mathrm{b}$ & 0.290 \\
\hline B3 (3) & Sfela & $0.169 \pm 0.030 \mathrm{a}$ & $5.27 \pm 0.29 \mathrm{~b}$ & 0.250 \\
\hline \multicolumn{5}{|c|}{ Gruyère type } \\
\hline G1 (6) & Graviera Kritis & $0.029 \pm 0.009 \mathrm{~b}$ & $5.35 \pm 0.73 b$ & 0.198 \\
\hline G2 (3) & Graviera Naxou & $0.028 \pm 0.007 \mathrm{~b}$ & $7.97 \pm 1.37 \mathrm{c}$ & 0.292 \\
\hline \multicolumn{5}{|c|}{ Hard type } \\
\hline H1 (5) & Kefalograviera & $0.067 \pm 0.026 \mathrm{~b}$ & $4.34 \pm 1.02 \mathrm{a}, \mathrm{b}$ & 0.177 \\
\hline H2 (3) & Ladotyri Mytilinis & $0.030 \pm 0.016 \mathrm{~b}$ & $5.80 \pm 1.02 \mathrm{~b}$ & 0.218 \\
\hline H3 (3) & San Michali & $0.032 \pm 0.009 \mathrm{~b}$ & $12.40 \pm 1.72 \mathrm{~d}$ & 0.381 \\
\hline \multicolumn{5}{|c|}{ Pasta filata } \\
\hline P1 (9) & Kasseri & $0.050 \pm 0.026 \mathrm{~b}$ & $7.25 \pm 1.20 \mathrm{c}$ & 0.281 \\
\hline P2 (3) & Metsovone & $0.194 \pm 0.092 \mathrm{a}$ & $7.94 \pm 0.50 \mathrm{c}$ & 0.302 \\
\hline
\end{tabular}

Different letters indicate significantly different means $(P<0.05)$ within a column

${ }^{\text {a }}$ Number of samples in parenthesis

${ }^{\mathrm{b}} I M C U$ International Milk Clotting Units

${ }^{\mathrm{c}}$ One $\mathrm{U}$ is 0.1 change of A405 in $60 \mathrm{~min}$

${ }^{\mathrm{d}}$ Based on the composition values of Table 2

to inactivate residual enzyme. But, considerable residual chymosin activity has been also suggested by Farkye et al. (1991) and by Moatsou et al. (2001) based on their findings about proteolysis in Mozzarella and Kasseri cheese, respectively. Also, Bansal et al. (2009) have found higher residual activity in Mozzarella cheeses than in Emmental cheese. The explanation may be the low $\mathrm{pH}(\mathrm{pH} \sim 5.2)$ of the acidified cheese curd during kneading. The opposite is true for the hard type cheeses, in which the heat treatment is applied in the curd immediately after cutting at $\mathrm{pH} \sim 6.50$, which is close to milk pH. According to Garnot and Mollé (1987), an increase of $\mathrm{pH}$ in the range from 6.50 to 6.75 at $51{ }^{\circ} \mathrm{C}$ for 30 min results in a reduction of residual chymosin activity by about $60 \%$. Also, Hayes et al. (2002) report that there is a 17-fold linear increase in $D$ values of chymosin at $56.5^{\circ} \mathrm{C}$ as $\mathrm{pH}$ of the skim milk decreases from 6.64 to 6.20. Moreover, the "survival" of chymosin after pasta filata processing may be related to the findings of Bansal et al. (Bansal et al. 2007), who report that $\mathrm{pH}$ reduction to $<5.6$ increases the interaction of coagulant with casein micelles.

Finally, the relation between residual chymosin activity in cheese and the quantity and the IMCU of the rennet used in cheesemaking must be taken into consideration. The reports about the effect of rennet quantity are contradictory. It has been reported that rennet quantity is positively correlated with residual activity (Guinee and Wilkinson 1992). On the contrary, Bansal et al. (2007) reported recently that the 
quantity of chymosin added to milk up to fivefold above the normal level has no significant effect on the retention of chymosin in curd. Nevertheless, data about rennet quantity were not known for the analyzed market samples of the present study. But a comment could be added for Metsovone cheese. According to the standards of identity (Table 1), the curd of Metsovone is in general cut 10-15 min after rennet addition; therefore a rather high quantity of rennet may be used, that could explain the high residual chymosin activity in this cheese. Therefore, the general conclusion from the present results was that considering cheese varieties with similar moisture and $\mathrm{pH}$ the most critical factor for the chymosin residual activity in cheese is the conditions under which the cooking of curd pieces is carried out.

\subsection{Plasmin activity}

In contrast to residual chymosin, high $\mathrm{pH}$ values and increase of curd cooking temperature favor plasmin activity in cheese and increase also the rate of plasminogen activation during ripening (Somers et al. 2002). Accordingly, plasmin plus plasminogen-derived activity in low $\mathrm{pH}$ white brined cheeses Feta and Kalathaki made from noncooked curd was the lowest (Table 4), whereas the highest values were observed in hard type and pasta filata cheeses. In Table 4 is also presented the ratio plasmin/protein, which can be a more objective index for the evaluation of the results. Since it is known that plasmin system activity is connected to the casein micelles, it is expected that in similar cheeses with high protein content the activity of plasmin system is also high. This was very obvious in the $\mathrm{H} 3$ that is made from partially skimmed milk and had high protein content. The activity presented in Table 4 was measured under the $\mathrm{pH}$ and temperature conditions of the assay, meaning that plasmin is not expected to be active in Feta cheese $\mathrm{pH} \sim 4.4-4.6$. Furthermore, less variability was observed for plasmin values within each group of cheeses than for residual chymosin because plasmin is not added exogenously to cheese milk as happens with rennet. In conclusion, according to these findings, both two major proteolytic factors plasmin and chymosin were active in pasta filata cheese, which explains the extent of proteolysis in this cheese group (Table 3).

\subsection{Peptide profiles}

The RP-HPLC profiles were divided in four parts named 0, I, II, and III. Some of them with distinct characteristics are presented in Fig. 1. The contribution of the different parts in the total area of the profiles is shown in Table 5. The part 0 corresponds to the first $10 \mathrm{~min}$ of analysis, i.e., elution with $0 \%$ acetonitrile and includes mainly components of the cheese soluble extract that are not retained onto C18 column, i.e., some free amino acids and non-nitrogen soluble components. Analysis of standard mixtures of individual caseins and whey proteins by the same method in the same laboratory has shown that they are eluted after $85 \mathrm{~min}$, i.e., with $\geq 48 \%$ acetonitrile in the elution mixture (data not shown).

The profiles of the present study were compared with the findings of Gagnaire et al. (2001), who studied in detail the peptides of Emmental cheese water-soluble extract using a C18 column and a similar elution method. Taking into consideration, the molecular mass of the peptides that they identified came up that the mean 
molecular mass of the peptides eluted in each part of their chromatographic profiles is as follows: (1) part I, $0-16 \%$ acetonitrile: 732 g.mol ${ }^{-1}$ (from 388 to 1,435); (2) part II, 16-32\% acetonitrile 1,657 g.mol ${ }^{-1}$ (from 658 to 3,133); and (3) part III, $32-$ $48 \%$ acetonitrile $1,702 \mathrm{~g} . \mathrm{mol}^{-1}$ (from 770 to 3,479 ). In this last part also, individual caseins and whey proteins are eluted. Furthermore, according to these findings, the most part of cheese peptides originating from $\beta$-casein result from plasmin action at Lys28-Lys29 site and they are eluted within 16-32\% acetonitrile. Ferranti et al.

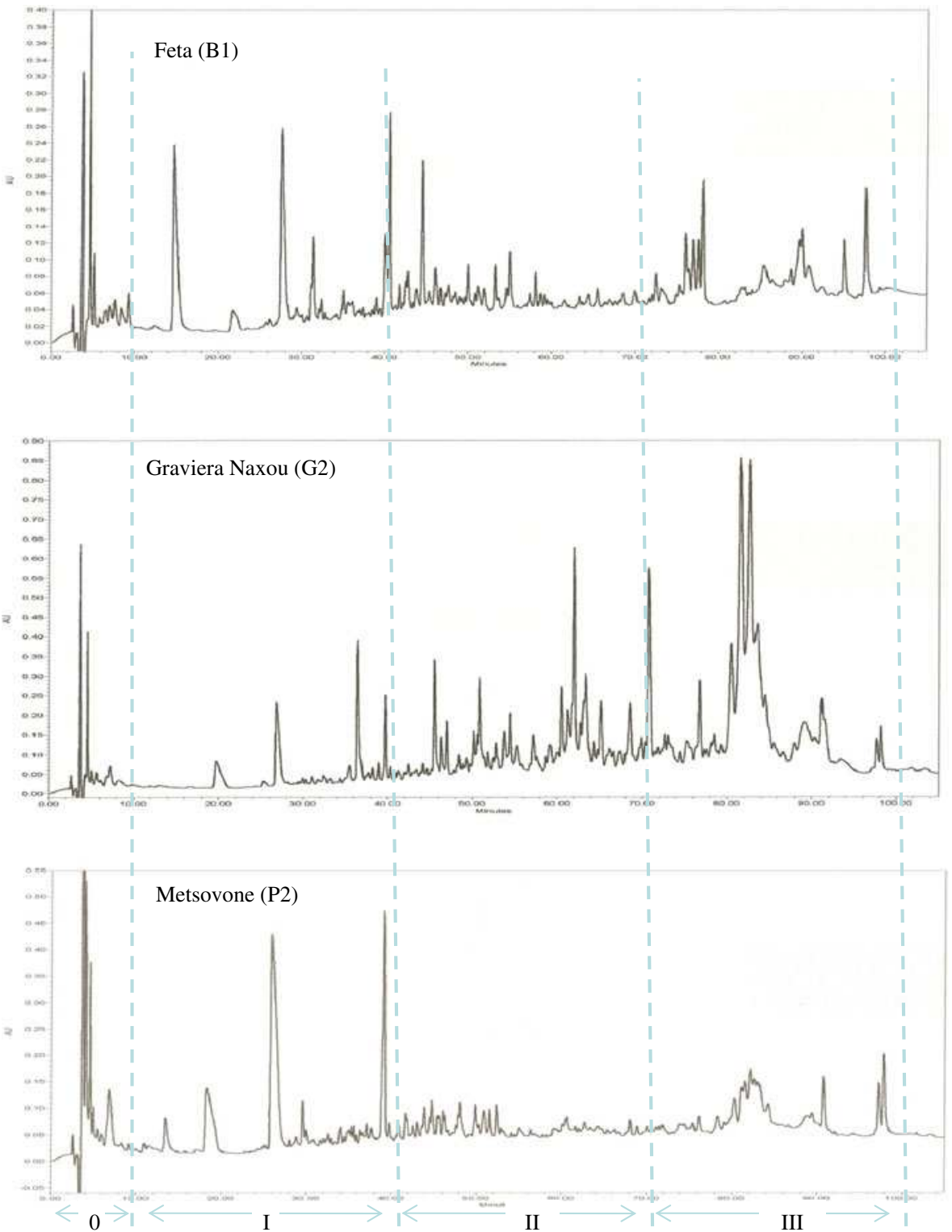

Fig. 1 RP-HPLC profiles (A220) of the soluble $N$ fractions of various cheese varieties. Symbols $0, I, I I$, and $I I I$ are explained in Table 5. The analysis method is described in Section 2.4 
Table 5 Different parts of RP-HPLC profiles of SN fraction of various cheeses expressed as mean percentage of the total area

\begin{tabular}{|c|c|c|c|c|c|c|c|}
\hline $\operatorname{Code}^{\mathrm{a}}$ & Cheese variety & $\begin{array}{l}\text { Part } 0 \\
0-10 \text { min } \\
0 \% \text { ACN }\end{array}$ & $\begin{array}{l}\text { Part I } \\
10-40 \mathrm{~min} \\
0-16 \% \mathrm{ACN}\end{array}$ & $\begin{array}{l}\text { Part II } \\
40-70 \mathrm{~min} \\
16-32 \% \mathrm{ACN}\end{array}$ & $\begin{array}{l}\text { Part III } \\
70-100 \mathrm{~min} \\
32-48 \% \mathrm{ACN}\end{array}$ & $\begin{array}{l}55-100 \min ^{-} \\
/ 10-55 \min ^{\mathrm{b}}\end{array}$ & $\begin{array}{l}40-70 \\
/ 10-40 \mathrm{~min}^{\mathrm{b}}\end{array}$ \\
\hline \multicolumn{8}{|l|}{ Brined } \\
\hline B1 (19) & Feta & $12.3 \mathrm{~b}, \mathrm{c}$ & $23.0 \mathrm{a}, \mathrm{b}, \mathrm{c}$ & $38.5 \mathrm{a}$ & $24.3 \mathrm{e}$ & $0.80 \mathrm{c}$ & $2.18 \mathrm{a}, \mathrm{b}$ \\
\hline B2 (3) & Kalathaki Limnou & $10.3 \mathrm{c}, \mathrm{d}$ & $18.3 \mathrm{~b}, \mathrm{c}$ & $37.9 \mathrm{a}$ & 28.9 b,c,d,e & $0.98 \mathrm{c}$ & $2.40 \mathrm{a}, \mathrm{b}$ \\
\hline B3 (3) & Sfela & $11.6 \mathrm{c}, \mathrm{d}$ & $22.2 \mathrm{a}, \mathrm{b}, \mathrm{c}$ & $34.8 \mathrm{a}, \mathrm{b}$ & $27.1 \mathrm{c}, \mathrm{d}, \mathrm{e}$ & $0.98 \mathrm{c}$ & $1.66 \mathrm{a}, \mathrm{b}$ \\
\hline \multicolumn{8}{|c|}{ Gruyère type } \\
\hline G1 (6) & Graviera Kritis & $12.5 \mathrm{~b}, \mathrm{c}$ & $18.1 \mathrm{~b}, \mathrm{c}$ & $29.8 \mathrm{a}, \mathrm{b}$ & $35.0 \mathrm{~b}, \mathrm{c}, \mathrm{d}$ & $1.45 \mathrm{~b}, \mathrm{c}$ & $1.68 \mathrm{a}, \mathrm{b}$ \\
\hline G2 (3) & Graviera Naxou & $5.8 \mathrm{~d}$ & $11.0 \mathrm{c}$ & $30.1 \mathrm{a}, \mathrm{b}$ & $52.0 \mathrm{a}$ & $3.05 \mathrm{a}$ & $2.86 \mathrm{a}$ \\
\hline \multicolumn{8}{|c|}{ Hard type } \\
\hline H1 (5) & Kefalograviera & $16.0 \mathrm{c}$ & $22.0 \mathrm{a}, \mathrm{b}, \mathrm{c}$ & $27.6 \mathrm{a}, \mathrm{b}$ & 30.8 b,c,d,e & $1.11 \mathrm{c}$ & $1.49 \mathrm{a}, \mathrm{b}$ \\
\hline H2 (3) & Ladotyri Mytilinis & $15.9 \mathrm{~b}, \mathrm{c}$ & $20.2 \mathrm{a}, \mathrm{b}, \mathrm{c}$ & $28.2 \mathrm{a}, \mathrm{b}$ & 30.8 b,c,d,e & $1.03 \mathrm{c}$ & $1.44 \mathrm{a}, \mathrm{b}$ \\
\hline H3 (3) & San Michali & $12.4 \mathrm{~b}, \mathrm{c}$ & $23.9 \mathrm{a}, \mathrm{b}$ & $22.3 \mathrm{~b}$ & $38.6 \mathrm{~b}$ & $1.30 \mathrm{~b}, \mathrm{c}$ & $0.95 \mathrm{~b}$ \\
\hline \multicolumn{8}{|c|}{ Pasta filata type } \\
\hline P1 (9) & Kasseri & $11.1 \mathrm{c}, \mathrm{d}$ & $16.9 \mathrm{~b}, \mathrm{c}$ & 33.9 a,b & $36.0 \mathrm{~b}, \mathrm{c}$ & $1.79 \mathrm{~b}$ & $2.18 \mathrm{a}, \mathrm{b}$ \\
\hline P2 (3) & Metsovone & $16.0 \mathrm{~b}, \mathrm{c}$ & $31.3 \mathrm{a}$ & $24.4 \mathrm{~b}$ & $24.4 \mathrm{~d}, \mathrm{e}$ & $0.80 \mathrm{c}$ & $0.81 \mathrm{~b}$ \\
\hline
\end{tabular}

$A C N$ acetonitrile

Different letters indicate significantly different means $(P<0.05)$ within a column

${ }^{a}$ Number of samples in parenthesis

${ }^{b}$ Ratio of the areas of the peaks eluted in these parts of the chromatograms 
(1997) reported similar results about oligopeptides of Grana-Padano cheese that come from $\beta$-casein.

It is interesting to note that the part $10-55 \mathrm{~min}$ of the present profiles, i.e., $0-24 \%$ acetonitrile was negatively significantly $(P<0.01)$ correlated with plasmin activity presented in Table $4(R=-0.538)$, whereas it was positively correlated to chymosin activity $(R=0.532)$. Therefore, plasmin activity accumulates peptides mostly in the rare part of the profiles and residual chymosin activity results in the increase of the peaks in the front part. In general, the ratio area 55-100 min to area 10-55 min was higher in the cheeses with low residual chymosin activity (Tables 4 and 5). However, the contribution of starter and NSLAB proteolytic enzymes in the accumulation of small peptides must be taken into account. Finally, the ratio area 40-70/10-40 was correlated linearly, negatively, significantly $(P<0.01)$ with \% PTA-SN/TN $(R=-0.460)$.

\subsection{Principal component analysis}

The PCA based on the results of all analyses presented in Tables 2, 3, 4, and 5 is shown in Table 6 and Fig. 2. Five components with eigenvalues greater than 1 have been extracted, that all together account for the $86.8 \%$ of the variability. It is

Table 6 Principal component analysis based on the biochemical analyses data (Tables 2, 3, 4, and 5); only components with eigenvalues greater than 1 have been considered

\begin{tabular}{|c|c|c|c|c|c|}
\hline & Component 1 & Component 2 & Component 3 & Component 4 & Component 5 \\
\hline Eigenvalue & 5.133 & 2.792 & 1.882 & 1.256 & 1.082 \\
\hline $\begin{array}{l}\text { Cumulative percentage } \\
\text { of variance }\end{array}$ & 36.7 & 56.6 & 70.1 & 79.0 & 86.8 \\
\hline \multicolumn{6}{|l|}{ Component weights $^{\mathrm{a}}$} \\
\hline Moisture & 0.375 & -0.076 & -0.097 & 0.205 & 0.206 \\
\hline $\mathrm{pH}$ & -0.378 & 0.035 & -0.096 & -0.125 & -0.193 \\
\hline FDM & 0.339 & -0.033 & 0.024 & -0.353 & -0.315 \\
\hline $\mathrm{PDM}^{\mathrm{b}}$ & -0.370 & 0.021 & -0.242 & 0.106 & 0.298 \\
\hline Ash & -0.238 & 0.127 & 0.573 & 0.136 & -0.054 \\
\hline $\mathrm{S} / \mathrm{M}$ & -0.113 & 0.180 & 0.654 & 0.131 & -0.015 \\
\hline$\% \mathrm{SN} / \mathrm{TN}$ & -0.212 & 0.137 & -0.215 & 0.272 & -0.629 \\
\hline$\% \mathrm{TCA}-\mathrm{N} / \mathrm{TN}$ & 0.012 & 0.434 & -0.210 & 0.282 & -0.332 \\
\hline$\%$ PTA-N/TN & 0.028 & 0.428 & -0.222 & 0.092 & 0.222 \\
\hline Part I & 0.079 & 0.528 & -0.025 & -0.272 & 0.160 \\
\hline Part II & 0.240 & -0.325 & -0.017 & 0.468 & -0.082 \\
\hline Part III & -0.297 & -0.367 & -0.045 & 0.078 & -0.060 \\
\hline Residual chymosin ${ }^{\mathrm{c}}$ & 0.249 & 0.177 & 0.085 & 0.527 & 0.131 \\
\hline Plasmin $^{\mathrm{c}}$ & -0.366 & -0.016 & -0.128 & 0.178 & 0.347 \\
\hline
\end{tabular}

\footnotetext{
${ }^{\text {a }}$ Variables are symbolized according to the respective Tables

${ }^{\mathrm{b}}$ Protein on dry matter

${ }^{\mathrm{c}}$ Activity
} 

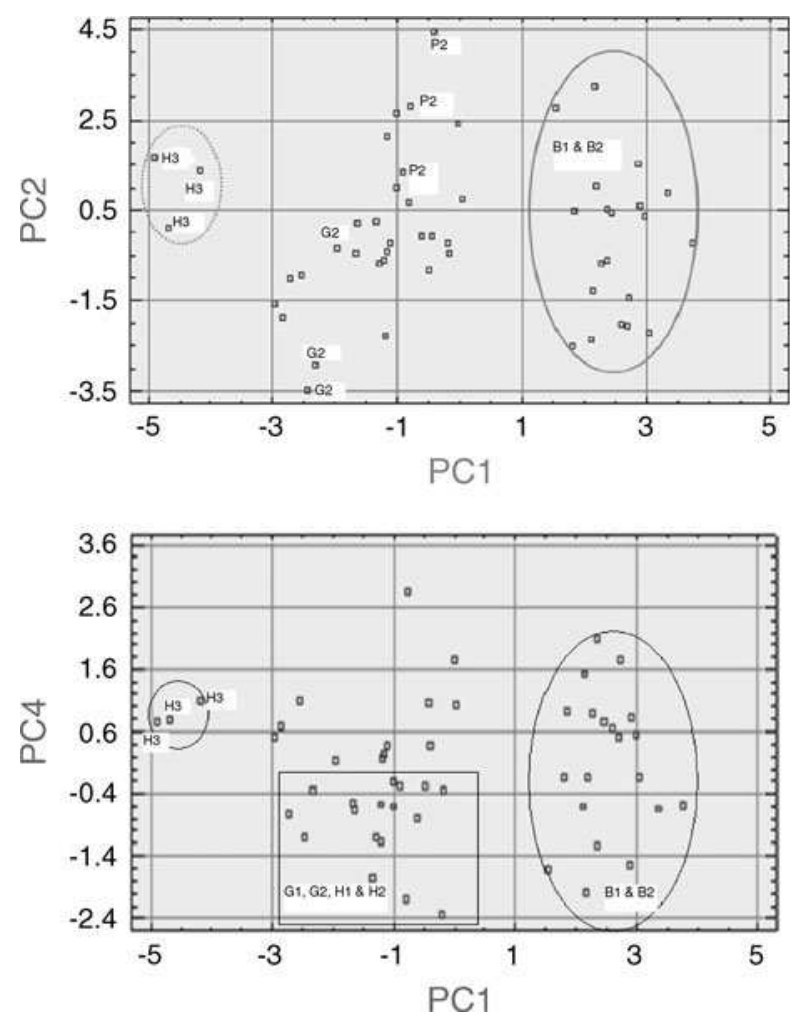

Fig. 2 Plots of principal components based on the biochemical analyses (see Table 6). PC1, PC2, and PC4 accounted for $32.8 \%, 26.9 \%$, and $9.9 \%$ of variance. B1 Feta, B2 Kalathaki Limnou, G1 Graviera Kritis, G2 Graviera Naxou, H1 Kefalograviera, H2 Ladotyri Mytilinis, H3 San Michali cheeses

interesting to note that apart from composition variables, the enzyme activities and different parts of RP-HPLC profiles play a significant role although to opposite direction in the configuration of PC1 and PC4. PC1 separated the cheeses according to moisture and fat on dry matter (FDM; positively associated with PC1) and $\mathrm{pH}, \mathrm{PDM}$ and plasmin (negatively associated with PC1). (PC2) was associated positively with nitrogen fractions of the cheeses that did not differ significantly (Table 3). It was also positively associated with part I of the RP-HPLC profiles and negatively with parts II and III. Residual chymosin activity was mainly associated with PC4, in which also part II of the RP-HPLC profiles contributed considerably. Both these variables were positively correlated as mentioned in the previous paragraph.

Considering PC1, it was evident (Fig. 2) that Feta and Kalathaki Limnou brined cheeses (B1 and B2), which are in fact very similar to each other in terms of cheesemaking technology were grouped separately from other cheeses. The same was also true for $\mathrm{H} 3$ that are made from reduced fat milk; therefore their PDM and FDM contents and plasmin activity differentiate them from all other cheeses. The part I of the RP-HPLC profiles was significantly different $(P<0.05)$ between P2, i.e., highest value and G2, i.e., lowest value (Table 5). This difference differentiated clearly these two cheese varieties (Fig. 2). With the exception of H3 and two 
Kefalograviera samples, all Gruyère and hard type cheeses with significantly lower $(P<$ 0.05 ) residual chymosin contents (Table 4 ) had negative PC1 and PC4 values (Fig. 2)

In conclusion, only differences among cheesemaking conditions like the absence of cooking and pressing or the modification of the composition of cheese milk classified clearly the cheeses of the present study by means of PCA analysis. Moreover, it was evident that cheeses could not be clearly grouped by means of PCA according to their residual chymosin and plasmin activities.

\section{Conclusion}

According to the findings of the present study, there was not a typical proteolysis pattern in the market samples of various cheese groups, with regard to nitrogen fractions. However, RP-HPLC profiles of the $\mathrm{SN}$ fractions were related to proteolysis characteristics of each group of cheese. Particular parts of the RPHPLC profiles of the soluble fractions of cheeses provided evidence about the activity of the major proteolytic factors. In low $\mathrm{pH}$ high-moisture brined cheeses, high residual chymosin and low plasmin plus plasminogen-derived activities were observed. The opposite was true for hard type cheeses especially for Gruyere type in which high-cooking temperatures for rather long time are applied in the curd pieces. It was concluded that in pasta filata cheeses, the low $\mathrm{pH}$ of the biologically acidified cheese mass "protected" the enzyme during the severe heating conditions applied during kneading. The high activities observed for both plasmin and residual chymosin in pasta filata type cheeses were in accordance to their extent of proteolysis. Finally, the absence of cooking and pressing and the modification of cheesemilk composition differentiated the cheese varieties of the present study by means of PCA.

Acknowledgments We would like to thank the Programme of Postgraduate Studies "Food Science and Nutrition", Department of Chemistry, University of Ioannina, for contribution to the financing of this study.

\section{References}

Albenzio M, Caroprese M, Santillo A, Marino R, Taibi L, Sevi A (2004) Effects of somatic cell count and stage of lactation on the plasmin activity and cheesemaking properties of ewe milk. J Dairy Sci $87: 533-542$

Alichanidis E, Polychroniadou A (2008) Characteristics of major traditional regional cheese varieties of East-Mediterranean countries: a review. Le Lait 88:495-510

Amenu B, Deeth HC (2007) The impact of milk composition on Cheddar cheese manufacture. Aust J Dairy Technol 62:171-184

Baer A, Collin JC (1993) Determination of residual activity of milk-clotting enzymes in cheese specific identification of chymosin and its substitution in cheese, Bulletin 284, pp 18-23. International Dairy Federation, Brussels

Baer A, Rybal I, Carey M (1997) Influence of coagulating enzymes and plasmin on the growth of starter bacteria at the start of Emmental cheese manufacture. Preliminary report. Le Lait 77:189-199

Bansal N, Fox PF, McSweeney PLH (2007) Factors affecting the retention of rennet in cheese curd. J Agric Food Chem 55:9219-9225

Bansal N, Fox PF, McSweeney PLH (2009) Comparison of the level of residual coagulant activity in different cheese varieties. J Dairy Res 76:290-293 
Benfeldt C, Sorensen J, Ellegard KH, Peterssen TE (1997) Heat treatment of cheese milk: effect on plasmin activity and proteolysis during cheese ripening. Int Dairy J 7:723-731

Cortellino G, Locci F, Rampilli M (2006) An investigation of the plasmin-plasminogen system in caprine milk and cheese. Int Dairy J 16:619-622

Dupont D, Grappin R (1998) ELISA for differential quantification of plasmin and plasminogen in cheese. J Dairy Res 65:643-651

Farkye N, Fox PF (1992) Contribution of plasmin to Cheddar cheese ripening: effect of added plasmin. J Dairy Res 59:209-216

Farkye NY, Kelly LJ, Allshouse RD, Kindsteadt PS (1991) Proteolysis in Mozzarella cheese during refrigerated storage. J Dairy Sci 74:1433-1438

Ferranti P, Itolli E, Barone F, Malorni A, Garro G, Laezza P, Chianese L, Migliaccio F, Stingo V, Addeo F (1997) Combined high resolution chromatographic techniques (FPLC and HPLC) and mass spectrometry-based identification of peptides and proteins in Grana Padano cheese. Le Lait 77:683697

Gagnaire V, Mollé D, Herrouin M, Léonil J (2001) Peptides identified during Emmental cheese ripening: origin and proteolytic systems involved. J Agric Food Chem 49:4402-4413

Garnot P, Mollé D (1987) Heat stability of milk cloting enzymes in conditions encountered in Swiss cheese making. J Food Sci 52:75-77/87

Greek Codex of Foodstuff and Drinks, Vol 2 (2009) General Chemical State Laboratory, Ministry of Economy and Finance, Hellenic Republic. http://www.dcsl.gr

Guinee TP, Wilkinson MG (1992) Rennet coagulation and coagulants in cheese manufacture. J Soc Dairy Technol 45:94-103

Hayes MG, Oliveira JC, Hurley MJ, Magboul AAA, Larsen LB, Heegaard CW (2001) Thermal inactivation kinetics of bovine cathepsin D. J Dairy Res 68:267-276

Hayes MG, Oliveira JC, McSweeney PLH, Kelly AL (2002) Thermal inactivation of chymosin during cheese manufacture. J Dairy Res 69:269-279

Hurley MJ, O’Driscoll BM, Kelly AL, McSweeney PLH (1999) Novel assay for the determination of residual coagulant activity in cheese. Int Dairy J 9:553-558

Hynes ER, Aparo L, Candioti MC (2004) Influence of residual milk-clotting enzyme on as1-casein hydrolysis during ripening of Reggiano Argentino cheese. J Dairy Sci 87:565-573

International Standard ISO 5943/IDF 88 (2006) Cheese and processed cheese products - determination of chloride content - potentiometric titration method. International Dairy Federation, Brussels

McSweeney PLH, Hayaloglu AA, O’Mahony JA, Bansal N (2006) Perspectives in cheese ripening. Aust J Dairy Technol 61:69-77

Moatsou G, Kandarakis I, Moschopoulou E, Anifantakis E, Alichanidis E (2001) Effect of technological parameters on the characteristics of Kasseri cheese made from raw or pasteurized ewes' milk. Int J Dairy Technol 54:69-77

Moschopoulou E, Kandarakis I, Anifantakis E (2007) Characteristics of lamb and kid artisanal liquid rennet used for traditional Feta cheese manufacture. Small Rumin Res 72:237-241

Politis I, Zavicion B, Barbano DM, Gorewit RC (1993) Enzymatic assays for the combined determination of plasmin plus plasminogen in milk: revisited. J Dairy Sci 76:1260-1267

Richardson BC, Pearce KN (1981) The determination of plasmin in dairy products. N Z J Dairy Sci Technol 16:209-220

Scherze I, Sienkiewicz T, Krenkel KC (1994) Studies on proteolytic degradation of caseins 2. Influence of plasmin on the proteolysis of Gouda cheese. Milchwissenschaft 49:564-569

Somers JM, Kelly AL (2002) Contribution of plasmin to primary proteolysis during ripening of cheese: effect of heat treatment and cheese cooking temperature. Le Lait 82:181-191

Somers JM, Guinee TP, Kelly AL (2002) The effect of plasmin activity and cold storage of cheese milk on the composition, ripening and functionality of mozzarella-type cheese. Int J Dairy Technol 55:5-11

Sousa MJ, Ardo Y, McSweeney PLH (2001) Advances in the study of proteolysis during cheese ripening. Int Dairy J 11:327-345 